\title{
Microbiological quality and HACCP of nono production in a Fulani settlement, Zaria Kaduna state, Nigeria
}

\author{
S. Bello ${ }^{*}$, V. J. Umoh ${ }^{2}$, M. Galadima ${ }^{3}$ and S. S. D. Mohammed ${ }^{4}$ \\ 1Department of Food Technology, Kaduna Polytechnic, Kaduna State, Nigeria. \\ ${ }^{2}$ Department of Microbiology, Akwa Ibom State University, Akwa Ibom, Nigeria. \\ ${ }^{3}$ Department of Microbiology, Federal University of Technology, Minna, Niger State, Nigeria. \\ ${ }^{4}$ Department of Microbiology and Biotechnology, Faculty of Natural and Applied and Sciences, Nile University of Nigeria, \\ Jabi, FCT, Abuja. \\ *Corresponding author. Email: sakeenabello2012@gmail.com
}

Copyright (C) 2020 Bello et al. This article remains permanently open access under the terms of the Creative Commons Attribution License 4.0, which permits unrestricted use, distribution, and reproduction in any medium, provided the original work is properly cited.

Received 2nd June, 2020; Accepted 29th June, 2020

\begin{abstract}
This research studied the frequency of occurrence of Escherichia coli, Bacillus cereus, yeasts and moulds in some retail uncontrolled fermented milk samples (nono), and a hazard analysis was conducted to trace the sources of contamination during processing and suggest critical control measures. Fifty (50) nono samples purchased from Fulani milkmaids in Samaru market of Zaria town, Kaduna, Nigeria, were analyzed for presence of E. coli, B. cereus, Yeasts and Moulds. The traditional processing of nono by 3 producers of some of the market samples analyzed was studied by observing processing steps, processing environment, collecting raw and fermented milk samples, cow dung, hand swabs, swabs of milk contact surfaces, and exposing sterile plates to milking environment. Nono processing for all 3 producers involved spontaneous fermentation of fresh unpasteurized milk in calabashes at ambient temperature $\left(25 \pm 4^{\circ} \mathrm{C}\right)$ for 24 hours, fat separation from fermented milk, addition of water, whisking, packaging in calabashes and storing at ambient temperature before sale. Mean plate counts of market nono samples were at levels considered unsatisfactory for $E$. coli $\left(\geq 10^{2}\right)$ in $76 \%$ of samples, potentially hazardous for $B$. cereus $\left(\geq 10^{4}\right)$ in $78 \%$ of samples and exceeded satisfactory limits for yeasts and moulds $(<10)$ in all samples $(100 \%)$. E. coli, B. cereus, yeasts and moulds were present in all 9 milk samples collected before and after fermentation during traditional processing. Yeasts and moulds were isolated from all samples $(100 \%)$ during traditional processing except for wooden spoons (78\%) and hand swabs (78\%). Substandard practices like using unclean hands in manual milking and use of unpasteurized milk observed during traditional processing could explain presence of these microorganisms in market samples, as was also detected in raw and fermented milk during traditional processing. Findings of this study support that of previous researchers which established the impact of substandard processing techniques and hygiene on food quality.
\end{abstract}

Keywords: B. cereus, control measures, E. coli, Fulani settlement, hazard analysis, nono, yeasts and moulds.

\section{INTRODUCTION}

Man has since time immemorial indulged in the preservation of food primarily to ensure food security; provide for days when the fresh supply is unavailable, and also to curtail losses when there is a surplus of the fresh supply. Preservation methods such as drying and fermentation appear to have been stumbled across by the initiators of such methods, as the principles of these methods were not fully understood then (Egwim et al., 2013). Today, not only has the basic principles of these methods been understood, but evolving technology has sought to exploit these principles to enhance the methods and improve on the quality of food products.

Fermented foods and beverages have for long been of considerable importance in the human diet as they usually 
have the qualities of enhanced shelf-life, palatability, safety and nutritional quality (Marco Maria et al., 2017). A variety of microorganisms have been associated with fermentations of wide variety of raw materials, fermentative behaviour and products. Consequently, there exists the risk of presence of microbial pathogens and toxic by-products of microbial origin which could reduce the safety of the consumed product. Fermentations can however be technologically driven such that desired attributes of quality and safety of the final products are made the focus of such fermentations (Capozzi et al., 2017).

Nigeria is a country endowed with a host of traditional foods and beverages made from rich supplies of raw food materials. These traditional food products constitute a part of street vended foods in the country. It has been documented that four out of every five Nigerians patronize street foods at least once a day (Wogu et al., 2011). Nono, is a popular beverage in northern Nigeria made from the uncontrolled fermentation of fresh, sometimes unpasteurized cow-milk (Maikai and Madaki, 2018). It is produced and vended by Fulani milkmaids in public places such as offices, schools, markets, cars/bus stations and a host of other public places.

Nono has yoghurt-like taste (sharp acid taste), and can be taken with sugar and /or fura (cooked millet flour which is rolled into small balls). As with other milk products, nono is an excellent source of protein, rich in essential amino acids and a good source of calcium, phosphorus and vitamin $A, B, C, E$ and $B$ complex. It is however poor in ascorbic acid and iron (Egwim et al., 2013). Nono production generally involves inoculating freshly drawn cow milk with a small quantity of leftover nono as starter, and then storing at room temperature for twenty-four hours. In some cases, nono is produced from spontaneous milk fermentation by environmental microbes (Akabanda et al., 2010). Nono producers also reportedly add stream water and other miscellaneous products such as the milky white supernatant of water-soaked baobab tree seed (kuka) to the fermented milk to add volume, taste and colour (Ladan and Abiodun, 1990).

The hazard analysis and critical control point also known as HACCP is a quality control tool that has over the years become synonymous with food safety assurance. The HACCP employs a systematic approach to the designing, monitoring and assurance of safe food products in a way that is pre-emptive rather than retrospective (Centre for Food Safety, 2017). It includes amongst other steps, the identification of hazards which are biological, chemical or physical agents in, or condition of food with the potential to cause an adverse health effect in a processing operation. This is followed by the establishment of critical control points (CCPs), which are steps at which control can be applied and are essential to prevent or eliminate a food safety hazards or reduce them to acceptable levels. Control measures which include actions and activities that can be used to prevent or eliminate food safety hazards or reduce them to acceptable levels can then be applied. In this way, food producers and indeed consumers are protected from not only producing and consuming unsafe foods, but also from the prospect of economic losses arising from potential hazards during processing (Bryan, 1992).

Nono still remains a popular street vended beverage amongst middle and low income earners in northern Nigeria in spite of a seemingly lack of proper training in safe food processing and handling techniques by vendors (Omotosho et al., 2013). This has consequently attracted numerous studies into its safety over the years. A number of these studies have established the presence of pathogenic bacteria in retail nono (Omotosho et al., 2013; Bello et al., 2014; Emmanuel et al., 2014; Maikai and Madaki, 2018).

This study was thus carried out to assess the microbiological quality of some retail uncontrolled fermented milk samples sold in Samaru market in Zaria town and conduct a simple hazard analysis of their processing by milkmaids in a Fulani settlement, to establish the sources of contamination and suggest control measures.

\section{MATERIALS AND METHODS}

\section{Sample collection, storage and analysis}

Fifty (50) nono samples were purchased from Samaru market of Zaria town, Kaduna state, from Fulani milkmaids. Samples were each collected in sterile universal bottles and transported to the laboratory, Department of Microbiology, Ahmadu Bello University, Zaria in ice pack containers. All samples were refrigerated and analyzed within 24 hours for the presence of $E$. coli (FAO, 1979), B. cereus (Mats et al., 1985), yeasts and moulds (Barnett et al., 1983). One millilitre of appropriate 10-fold dilutions of each sample was pour-plated on Eosin methylene blue agar (EMB) (Oxoid), Mannitol Egg yolk Polymyxin B agar (MYP) (Oxoid) and Potato Dextrose agar (PDA) (Oxoid), for the isolation of E. coli, B. cereus, yeasts and moulds respectively. The EMB and MYP plates were incubated at $37^{\circ} \mathrm{C}$ for 24 to 48 hours (until the appearance of distinct colonies). Isolates appearing bluish black with greenish metallic sheen on EMB plates were counted as presumptive $E$. coli, whereas colonies which were surrounded by bluish zones of clearance on reddish/pinkish background on MYP plates were counted as presumptive $B$. cereus. All presumptive isolates were counted and streaked on nutrient agar slants, incubated at $37^{\circ} \mathrm{C}$ for 24 hours and stored at $4^{\circ} \mathrm{C}$ until characterized biochemically as described in Bergey's Manual for Determinative Bacteriology (Holt, 1994). PDA plates were incubated at room temperature $\left(25 \pm 3^{\circ} \mathrm{C}\right)$ for 3 to 5 days following which colonies were counted and recorded for yeasts and mould counts. 


\section{HACCP of nono processing}

\section{Selection of producers}

Three producers of some of the market samples of locally fermented milk (nono) analyzed were selected for hazard analysis studies. Selection was based on consent of the producers to visit their processing sites on 3 separate occasions for the analysis. A total of 9 samples each of raw milk, fermented milk, and water, 9 swabs each of the hands of the milker, calabashes, wooden spoons and whisks, and 6 samplings of the air of the milking environment were obtained during the study.

\section{Description of Settlement, living and milking activities}

Producer 1: Producer one lived in 1 of 10 to 12 mud huts of Biye settlement. Biye is situated about 8 kilometres west of Samaru village, after large cereal farms cultivated by the inhabitants of a neighbouring village (Agir) and to a small extent by some of the nomads. The producer had no access to pipe borne water and electrification facilities. Water was obtained by walking about $2 \mathrm{~km}$ daily to Agir village to fetch water for daily use from wells. Toilet and bath facilities for this producer included a pit latrine dug on a small portion of land surrounded by straw mats. This was situated about $6 \mathrm{~m}$ from the producer's hut which she shared with her husband and 2 children (Figure 1)

The producer had 6 cows and calves which she kept out in the open field about $15 \mathrm{~m}$ from her hut (Figure 2). This small area, referred to as "walde" had short strong sticks buried in the ground onto which ropes were attached. These ropes were used to secure the legs of the cows to stop them from straying. The ground was richly covered with cow dung and urine as no effort was ever made to clean up the place. As such the underside and limbs of the cows were always covered in cow dung and urine.

Household activities were carried out in the area just outside the producer's hut. Here she spread cereal grains on the ground, washed her kitchen utensils, and also cooked for her family. The cooking was sometimes done inside a hut when it was windy or raining. Washed cooking utensils, calabashes, wooden spoons, whisks, and gourds, which were all used during nono processing were placed on heaps of sticks in the sun to dry beside the huts (Figure 3). Domestic animals like goats and poultry were observed littering around this area. Human faeces was also observed dotted around areas beside the huts, and this was attributed to children who sometimes defecated indiscriminately around the huts.

Producer 2: Producer two also lived in a hut about $15 \mathrm{~m}$ from producer 1 and shared this hut with her husband and 3 children. This producer also obtained water from Agir village daily, and shared the same toilet and bath facilities with producer 1 . Household chores such as washing and cooking were done in the area in front of the producer's hut. Producer 2 had a total of 4 cows and 2 calves which were kept on the same walde as those of producer 1.

Producer 3: This producer also lived in a hut about $30 \mathrm{~m}$ from producer 1 . She shared this mud hut with her husband and one child. Like producers 1 and 2, she walked daily to Agir village to fetch water for daily use. A small portion of land surrounded by straw mats enclosed a pit latrine used by the producer and her family. This was situated some $6 \mathrm{~m}$ behind the hut. Like producers 1 and 2 , this producer carried out household chores in the area in front of her hut. The producer had a total of 3 cows and 2 calves which were kept out in the open field some metres from her hut.

\section{Milking of cows}

This was usually done between 9:00 and 10:00 am in the morning, on the walde. Milking was done by one individual (male) for all the producers. First, the calves were made to suckle to initiate milk flow before milking began. Once milk flow began, the calve was removed by the milkman, who without washing his hands, and without cleaning the udder, stooped under the cow with a clean, sundried calabash positioned between his knees and began a rhythmic pulling of the udder. As he did this, milk flowed into the calabash between his knees until the calabash was half filed (Figures 4 and 5). At this stage, the milk flow had greatly reduced from the cow. The calabash was then handed over to an assistant who then gave the milkman another empty calabash into which milk was also half filled from the same cow or filled to the brim with milk from another cow. Milking was done until all the nursing cows had been milked. The milkman then moved onto the next walde and repeated the same procedure as described above. It was observed that during the entire milking operation, the hands of the milkman were not washed or cleaned (when milking from cow to cow in one walde and between the 2 groups of cows in both waldes). Some of the raw milk was given to children to drink immediately it was collected from the cows (Figure 6).

\section{Nono production}

Milk processing into nono following milking by producer 1 , involved merely storing the calabashes of raw milk in her hut. Storage of calabashes inside the hut for spontaneous fermentation begins when all the calabashes have been filled with milk. Calabashes were stored in the hut for a period of 24 hours until curdling of milk to produce what is known as nono. Prior to this, all calabashes containing milk were covered with straw mats and kept on the ground close to the milking area until it is filled with milk before taken into the huts. 


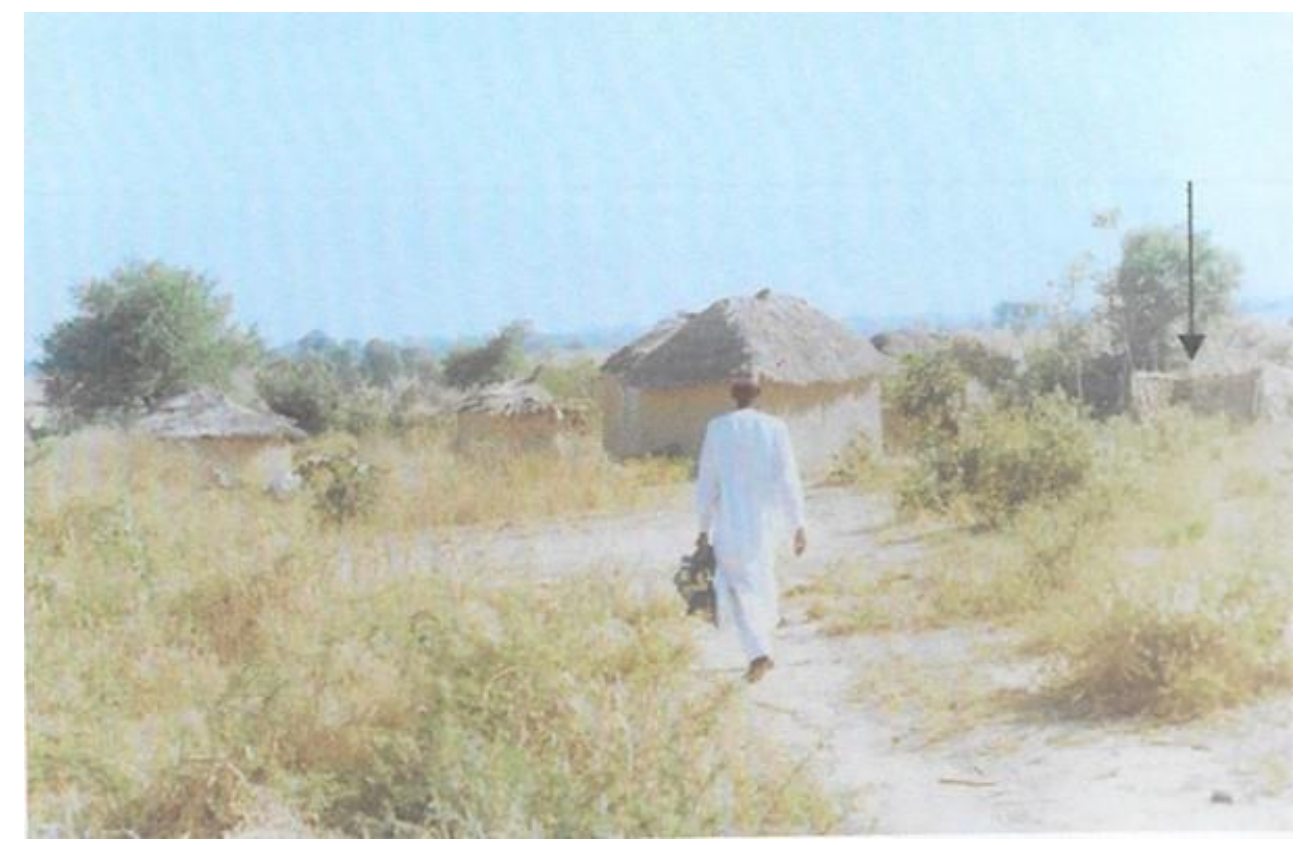

Figure 1. Biye settlement; Arrow shows toilet/bathroom at the far right end of the picture.

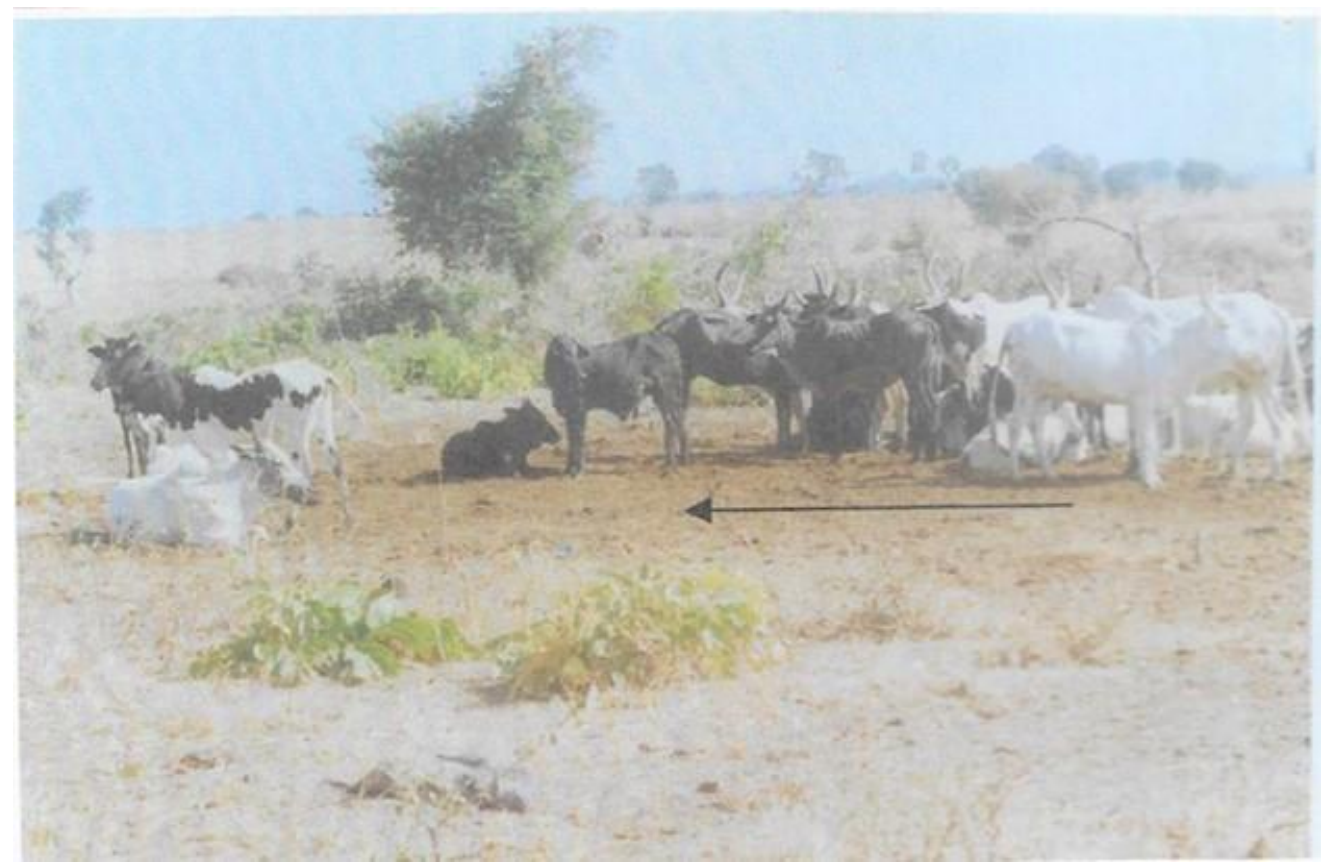

Figure 2. Arrow shows the ground richly covered with cow dung, and cows lying over it.

After fermentation of the milk, some of the milk fat, which formed a layer over the nono, was scooped with a clean wooden spoon and placed into a gourd. A small quantity of water was then added to the gourd, which was then shaken until the fat formed clumps in the gourd. This was then poured into another clean calabash (Figures 7 and 8).

The clumps of fat were then separated from the water by straining this water into the calabash of nono which was then whisked using a locally made wooden whisk. The calabashes of nono having been separated from the layers of fat were altogether poured into a big calabash which had been lined with polythene bag. This was then covered with a straw mat, and taken almost immediately to the market for sale (Figure 9). Producers 2 and 3 also produced nono 


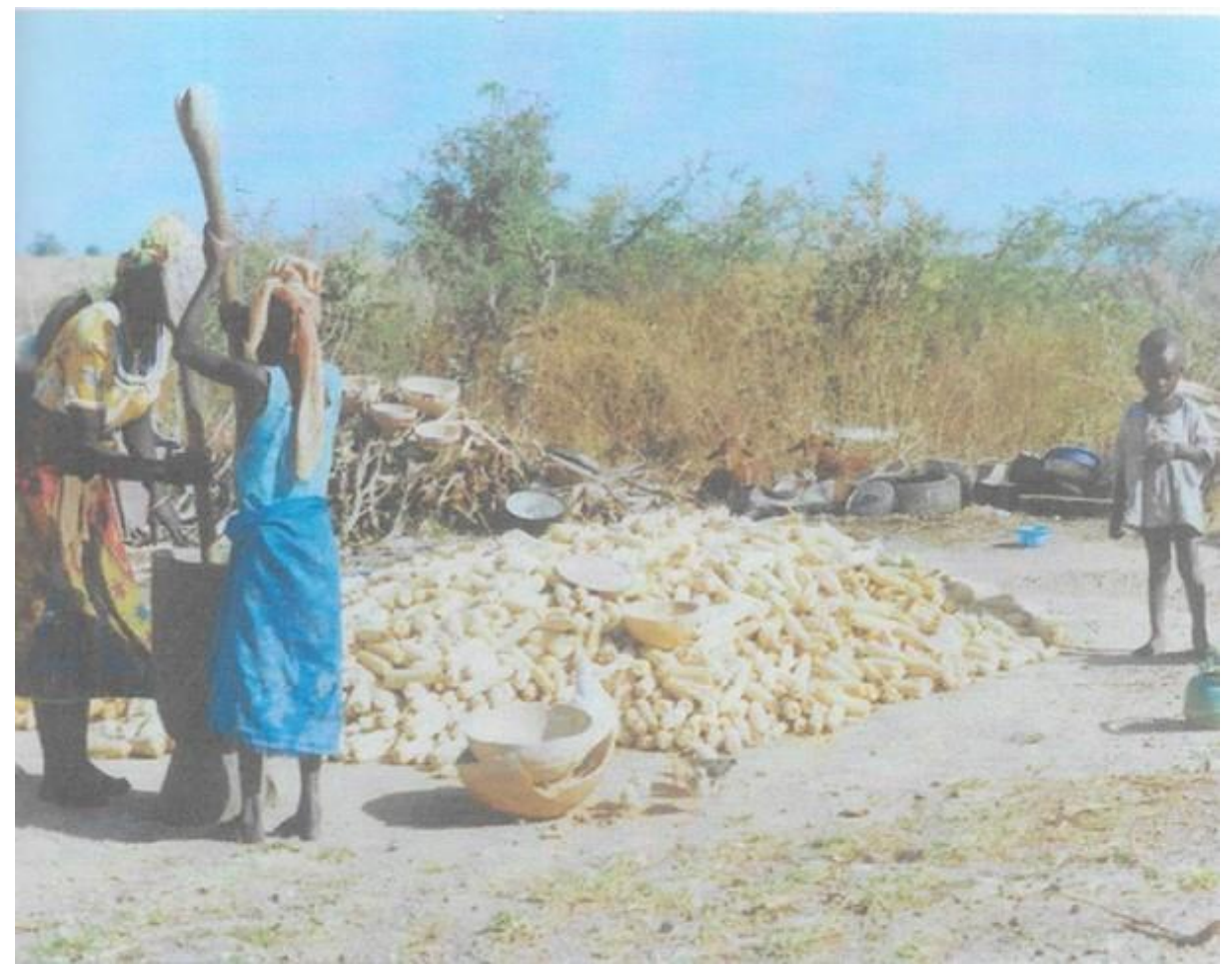

Figure 3. Area where household chores are carried out.

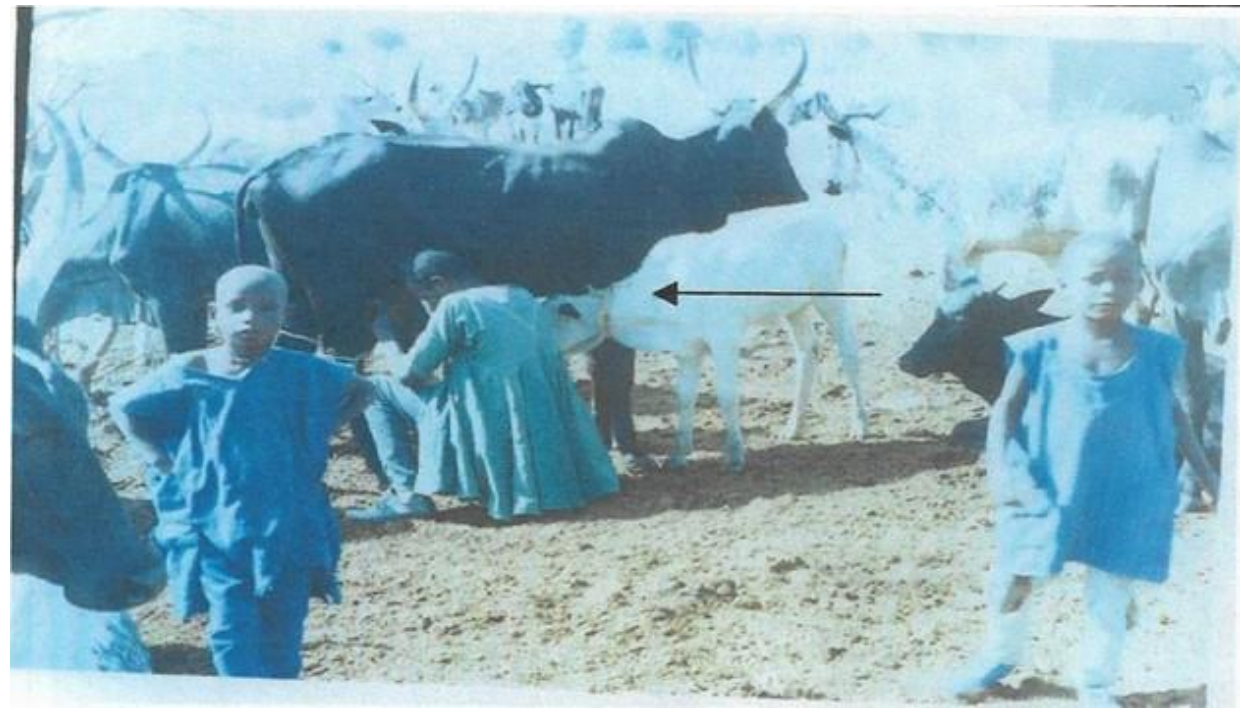

Figure 4. Milking about to begin. Arrow shows the calf which appears reluctant to leave its mother after initiating milk flow.

exactly the same way as did producer 1.

\section{Hazard analysis and sources of contamination of nono}

The traditional processing of nono by the 3 processors was studied by observing processing environment, processing steps, as well as collecting raw and fermented milk, specimens of cow dung, exposing sterile media to processing environment and taking swabs of milk contact surfaces and hand swabs (Lin et al., 1998). Milk temperature as well as temperature of milking environment were monitored using a mercury thermometer (camlab, UK) at intervals during production. Isolation of organisms 


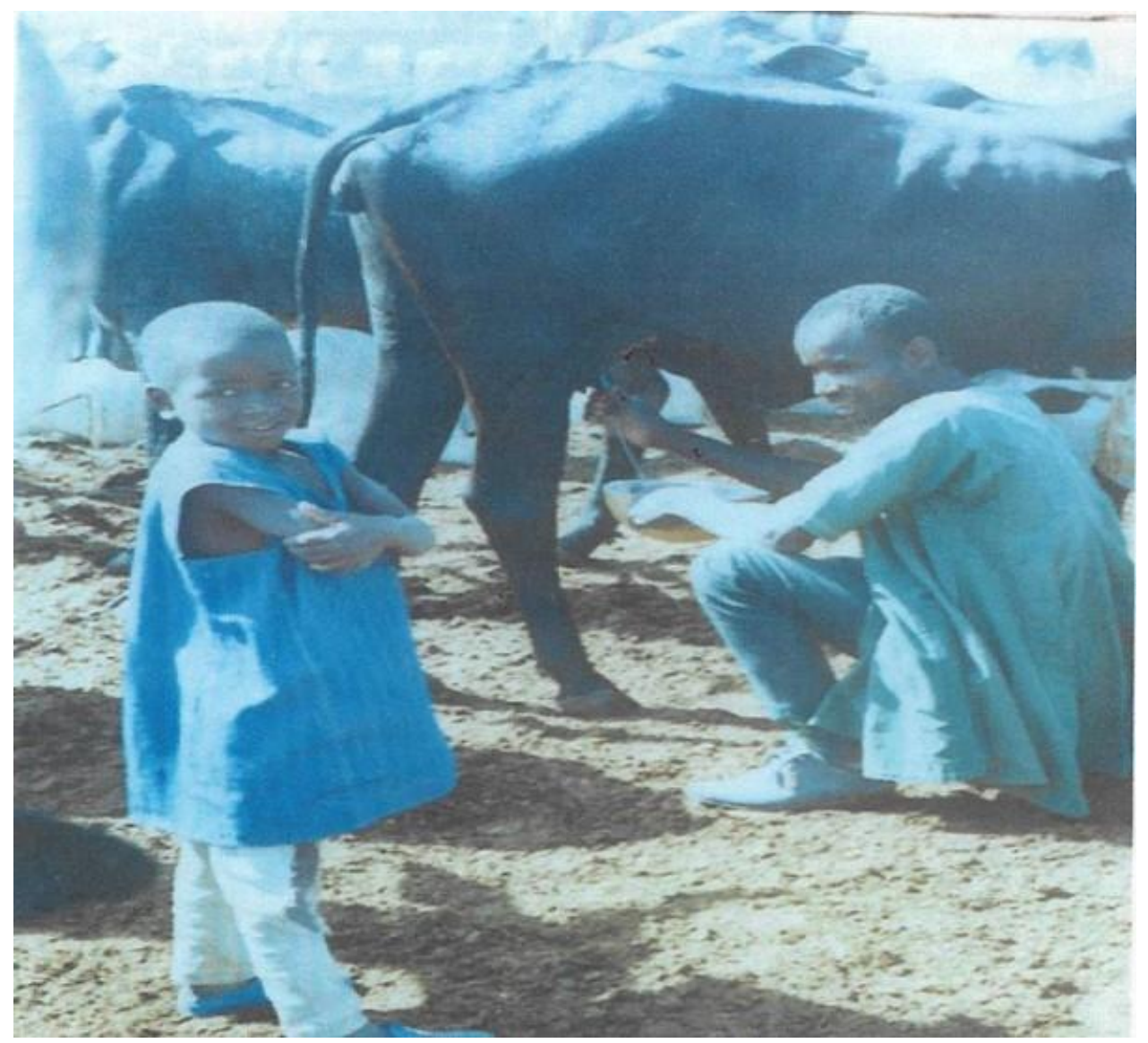

Figure 5. Milking in progress. The ground is richly covered with cow dung.

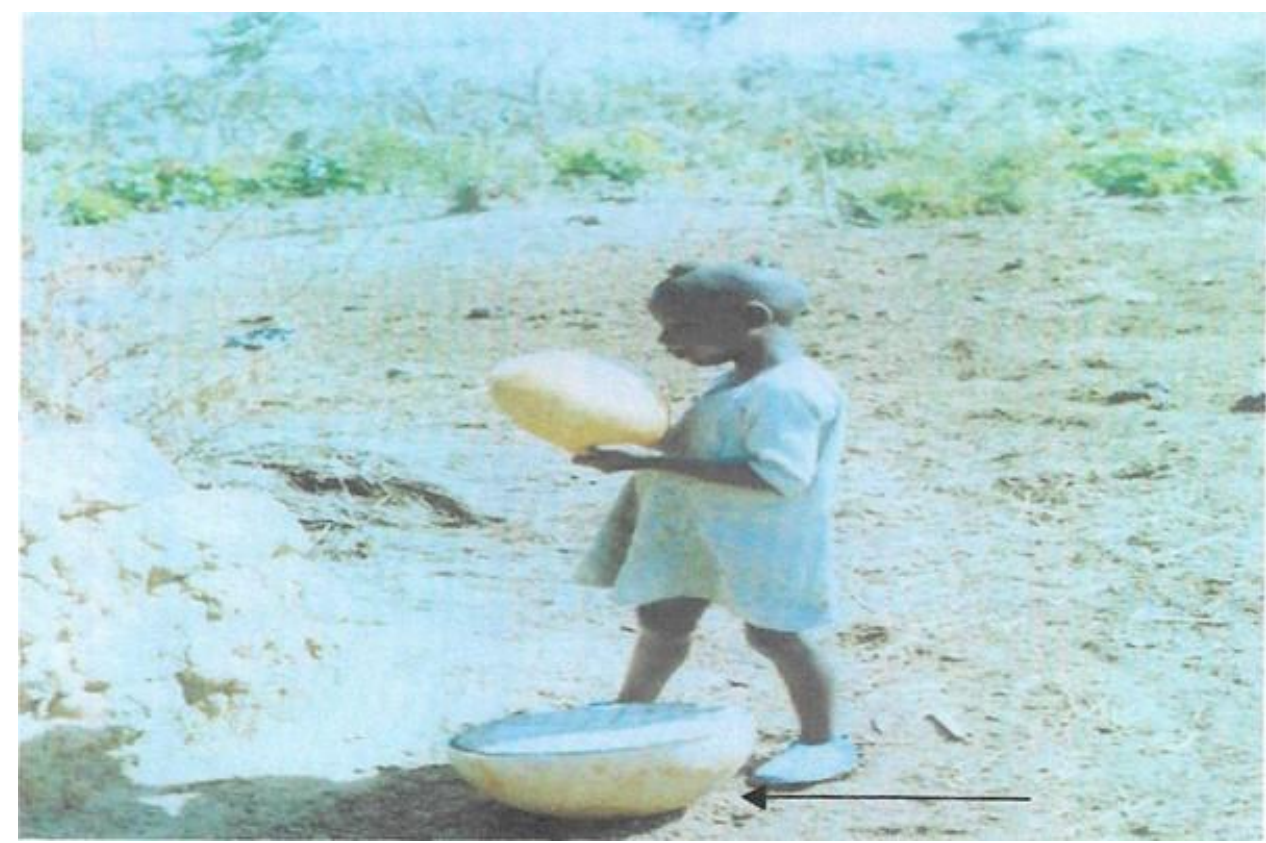

Figure 6. The child was caught unawares while licking the calabash of freshly drawn raw milk he had consumed. Arrow shows a calabash of milk by his foot prior to storage, placed on the ground contaminated with cow dung. 


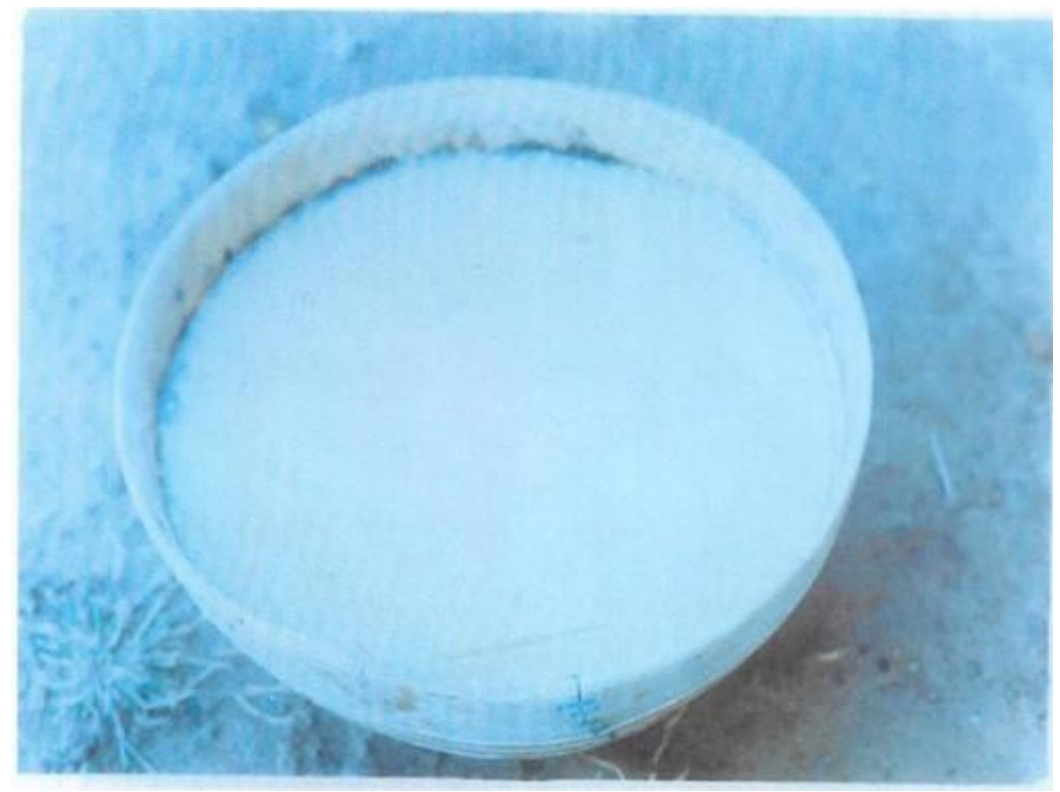

Figure 7. Calabash of fermented milk before removal of fat layer.

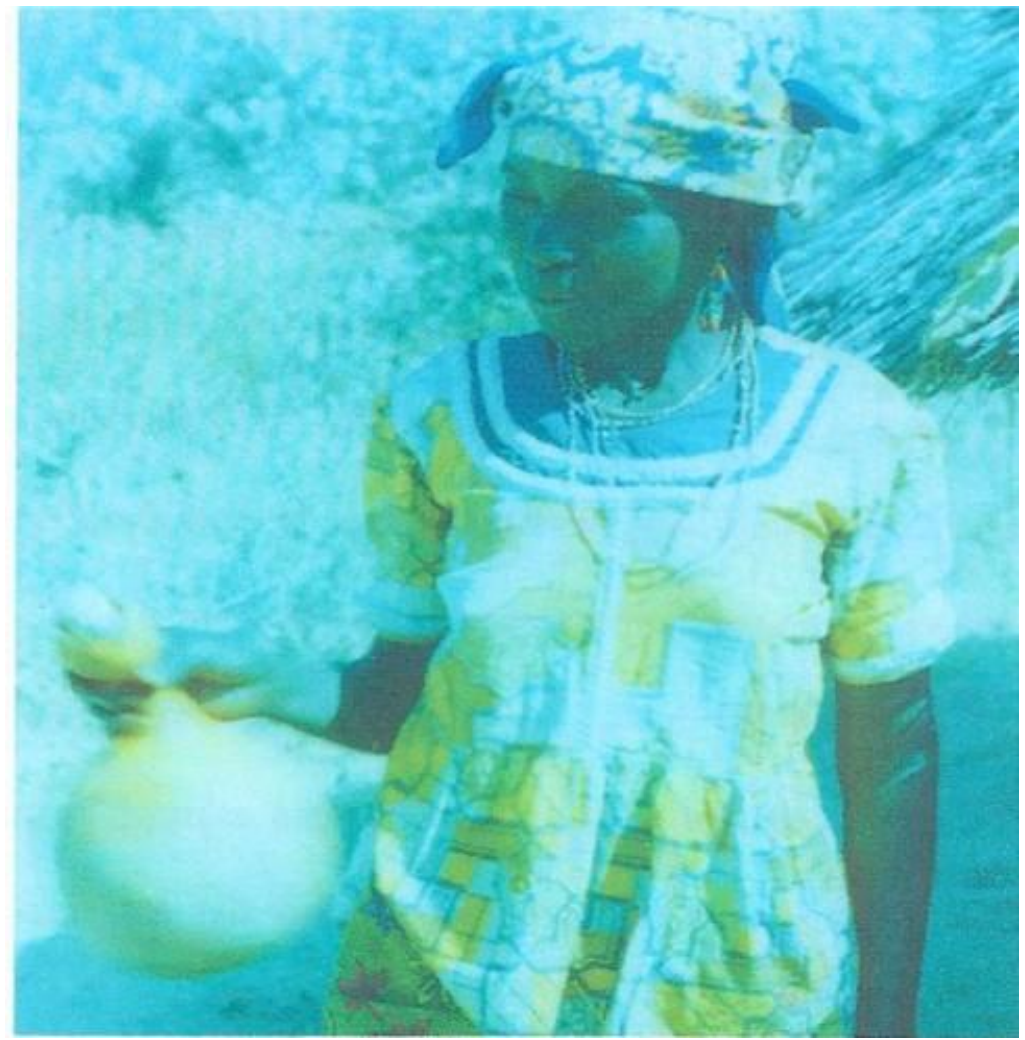

Figure 8. Separation of fat from fermented milk.

from the air of the milking environment involved exposing sterile plates of solidified MYP agar, acidified PDA, and EMB in the milking environment for 15,30 and 60 minutes. Specimens of cow dung were picked up with sterile spoon and dropped into sterile bottles containing normal saline (Duguid et al., 1994). All samples were transported in ice packed containers to the laboratory, Department of Microbiology, Ahmadu Bello University, Zaria for analysis. 


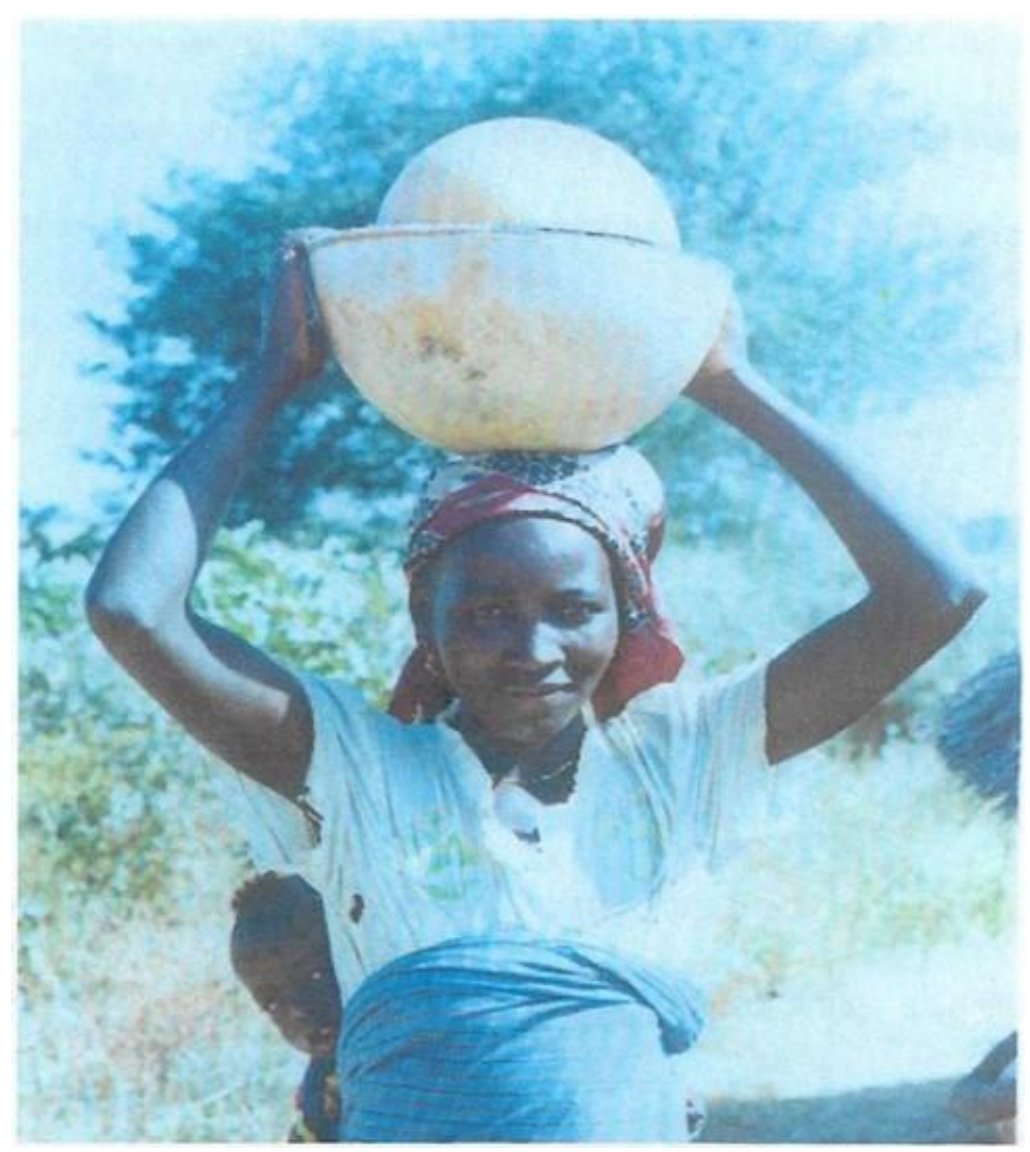

Figure 9. Nono ready for transportation to the market for sale.

Samples from processing areas were all analyzed for presence of E. coli, B.cereus, yeasts and moulds on appropriate isolation media. Biochemical characterization was carried out for all isolates from raw and fermented milk, milk contact surfaces and environmental samples obtained during traditional processing (Holt, 1994). Based on the observation and discussions made during nono processing, potential sources of contamination of the final product from raw materials, utensils, processors, chemical and other physical hazards in each step were noted and presented on Table 4 (Abd El-Razik et al., 2016).

\section{RESULTS AND DISCUSSION}

Frequency of occurrence and plate counts of Echerichia coli, Bacillus cereus, yeasts and moulds in nono

Results (Table 1 ) revealed the presence E. coli in 38 of $50(76 \%)$ nono samples. A total 39 samples $(78 \%)$ were positive for B.cereus, while yeasts and moulds were isolated from all $50(100 \%)$ nono samples. Escherichia coli counts (Table 2) ranged from $3.5 \pm 0.3$ to $6.4 \pm 0.3 \log _{10}$ $\mathrm{cfu} / \mathrm{ml}$ while $B$. cereus counts ranged from $4.0 \pm 1.2$ to
$6.0 \pm 0.7 \log _{10} \mathrm{cfu} / \mathrm{ml}$. Counts for yeasts and moulds ranged from $6.9 \pm 0.5$ to $7.9 \pm 0.9 \log _{10} \mathrm{cfu} / \mathrm{ml}$.

\section{HACCP of nono processing}

Results (Table 3 ) revealed that $E$. coli, B. cereus, yeasts and moulds were present in all raw milk samples during traditional processing and also after fermentation for 24 hours at ambient temperature $\left(25 \pm 4^{\circ} \mathrm{C}\right)$. E. coli unlike $B$. cereus, yeasts and moulds was not isolated from any of 9 $(100 \%)$ samples each of washed and sun dried calabashes, wooden spoons and whisks, 3 (100\%) samples of cow dung and $6(100 \%)$ samplings of milking areas. Yeasts and moulds had the highest recovery rate and were isolated from all of 9 samples each of raw and fermented milk $(100 \%)$, water samples $(100 \%)$, whisks $(100 \%)$, calabashes $(100 \%)$ and $6(100 \%)$ milking areas.

High prevalence rates were recorded of all organisms in this study $(>70 \%)$ and mean counts were at levels considered unsatisfactory for E. coli $\left(\geq 10^{2}\right)$ and potentially hazardous for $B$. cereus $\left(\geq 10^{4}\right)$ (NSW Food Authority, 2009). Mean plate counts for yeasts and moulds also exceeded satisfactory limits in all samples $(<10)$ (Adams and Moss, 1999). Processing conditions that were 
Table 1. Prevalence of Escherichia coli, Bacillus cereus, yeasts and moulds in retail Nono.

\begin{tabular}{|c|c|c|}
\hline Organism & Number of positive samples $(\mathrm{N}=50)^{*}$ & Percentage positive (\%) $(\mathrm{N}=50)^{\star}$ \\
\hline E. coli & 38 & 76 \\
\hline B. cereus & 39 & 78 \\
\hline Yeasts and moulds & 50 & 100 \\
\hline
\end{tabular}

*Total number of nono samples analyzed.

Table 2. Mean counts ${ }^{\star}$ of some pathogenic and spoilage microorganisms present in retail Nono.

\begin{tabular}{lccc}
\hline $\begin{array}{l}\text { Product/Producer } \\
(\mathbf{N}=50))^{* *}\end{array}$ & $\begin{array}{c}\text { Escherichia. coli } \\
(\mathbf{l o g} 10 \mathrm{cfu} / \mathbf{m l})\end{array}$ & $\begin{array}{c}\text { Bacillus cereus } \\
(\log 10 \mathrm{cfu} / \mathbf{m l})\end{array}$ & $\begin{array}{c}\text { Yeast and moulds } \\
(\mathbf{l o g} 10 \mathbf{c f u} / \mathbf{m l})\end{array}$ \\
\hline I & $4.5 \pm 12$ & $4.4 \pm 1.2$ & $7.3 \pm 0.8$ \\
II & $3.5 \pm 0.3$ & $5.1 \pm 1.2$ & $7.1 \pm 0.2$ \\
III & $5.6 \pm 0.0$ & $4.5 \pm 0.7$ & $6.9 \pm 0.5$ \\
IV & $4.8 \pm 1.4$ & $4.0 \pm 1.2$ & $7.3 \pm 0.6$ \\
V & $6.4 \pm 0.3$ & $5.8 \pm 0.7$ & $7.7 \pm 0.6$ \\
VI & $5.3 \pm 1.3$ & $5.6 \pm 0.9$ & $7.4 \pm 1.4$ \\
VII & $5.6 \pm 1.1$ & $5.4 \pm 1.4$ & $7.1 \pm 1.2$ \\
VIII & $5.8 \pm 0.5$ & $5.8 \pm 1.1$ & $7.7 \pm 0.5$ \\
IX & $6.1 \pm 1.1$ & $5.5 \pm 1.5$ & $7.9 \pm 0.9$ \\
X & $6.1 \pm 0.9$ & $6.0 \pm 0.7$ & $7.9 \pm 0.8$ \\
\hline
\end{tabular}

${ }^{*} \log 10 \mathrm{cfu} / \mathrm{ml} \pm$ standard deviation of 5 samples of each of 10 products/producers, ${ }^{* *}$ total number of samples analyzed.

observed during traditional processing in this study such as the use of unpasteurized milk, the absence of starter cultures and the addition of untreated water to the final product would have contributed significantly to the presence and growth of the spoilage and potentially pathogenic organisms in milk during nono production and subsequently in the final retail product. Similar studies into the quality of traditional milk and milk products have also associated processing conditions to the presence of spoilage and pathogenic microorganisms (Shehu and Adesiyun, 1990; Okonkwo, 2011; Okeke and Okwori, 2011; Mohammed and Abdullahi, 2013). Hazards were observed with most stages of nono processing in this study, the soil in the milking environment was richly covered with cow dung which could serve as a source of human pathogens such as $E$. coli. The hide of these animals can also comprise of organisms that originate from stomachs and intestines, which are excreted in their faeces (Norrung et al., 2009).

The soil on which the cows lay could serve as a source of $B$. cereus, yeasts and moulds. $B$. cereus is widely distributed in the environment, mainly in the soil, from which it is easily spread to many types of foods. It has been isolated from meat, milks and dairy products (Préstamo et al., 2007). Similarly, yeasts and mould spores are in abundance in the soil and air; they could be found growing on simple carbon sources in the soil and plant debris (Rawat, 2015). The settlement itself was observed to be surrounded by farmlands and this could provide an abundance of fungal and bacterial spores in the surroundings of the milking area.
Removing faeces and urine frequently from the living environment of the cows to prevent accumulation, shaving the udders, trimming tails as well as washing teats and surroundings with warm water containing disinfectant could serve as critical control points that will eliminate, prevent or minimize contamination from the udder and its immediate surroundings. Carving out or having cleaner areas for the milking process could also reduce the risk of contamination from the milking environment. The practice of initiating milk flow by making calves to suckle prior to milking is also likely to have increased the level of contamination of the milk samples. Employing the practice of washing the teats with disinfectant after discarding some quantity of fore milk from the teat following suckling by the calves could serve as a critical control point for this step. Another critical step would be to observe for signs of udder disease as well as abnormalities in milk characteristics and to reject such milk (Food Standards Agency, 2016).

During milking into calabashes, the milk samples were further subjected to contamination from the calabashes and the unwashed hands of the milkman. Analysis of hand swabs obtained during the study revealed the presence of E. coli, B. cereus, yeasts and moulds. Yeasts and moulds were also isolated from calabash swabs obtained during the study. Thorough washing of hands in soapy water containing detergent could serve to reduce or eliminate the bacterial load on the hands of the milkman. The milk calabashes could also be washed with warm soapy water and rinsed with clean water just before milk collection to reduce or eliminate further contamination of milk by the 
Table 3. Recovery frequency of organisms from milk and milk contact surfaces during traditional processing of Nono.

\begin{tabular}{|c|c|c|c|c|c|c|c|c|c|c|c|c|}
\hline \multirow{2}{*}{ Operation } & \multicolumn{4}{|c|}{ E. coli $(\mathrm{n}=9)$} & \multicolumn{4}{|c|}{ B. cereus $(\mathrm{n}=9)$} & \multicolumn{4}{|c|}{ Yeasts and moulds $(n=9)$} \\
\hline & P1 & P2 & P3 & No. +ve (\%) & P1 & P2 & P3 & No. +ve (\%) & P1 & P2 & P3 & No. +ve (\%) \\
\hline Raw milk before fermentation & 1 & 3 & 3 & $7(78)$ & 2 & 2 & 2 & $6(67)$ & 3 & 3 & 3 & $9(100)$ \\
\hline Raw milk after $24 \mathrm{~h}$ of fermentation & 1 & 3 & 3 & $7(78)$ & 2 & 2 & 2 & $6(67)$ & 3 & 3 & 3 & $9(100)$ \\
\hline Water & 0 & 2 & 1 & $3(33)$ & 2 & 2 & 1 & $5(56)$ & 3 & 3 & 3 & $9(100)$ \\
\hline Hand swabs & 1 & 3 & 3 & $7(78)$ & 0 & 1 & 2 & $3(33)$ & 1 & 3 & 3 & $7(78)$ \\
\hline Calabash & 0 & 0 & 0 & $0(0)$ & 1 & 0 & 0 & $1(11)$ & 3 & 3 & 3 & $9(100)$ \\
\hline Wooden spoon & 0 & 0 & 0 & $0(0)$ & 0 & 0 & 0 & $0(0)$ & 3 & 2 & 2 & $7(78)$ \\
\hline Whisk & 0 & 0 & 0 & $0(0)$ & 0 & 0 & 1 & $1(11)$ & 3 & 3 & 3 & $9(100)$ \\
\hline Cow dung* & 0 & 0 & 0 & $0(0)$ & 1 & 0 & 1 & $2(67)$ & 1 & 1 & 1 & $3(100)$ \\
\hline Milking area** & 0 & 0 & 0 & $0(0)$ & 3 & - & 3 & $6(100)$ & 3 & - & 3 & $6(100)$ \\
\hline
\end{tabular}

${ }^{*} \mathrm{n}$ (number of samples) for cow dung $=3$; **Producers 1 and 2 shared the same milking environment; P1 = Producer 1 ; P2 = Producer 2 ; P3 = Producer 3 .

Table 4. Hazards and control measures associated with the processing of uncontrolled fermented milk (nono) in a fulani settlement in Zaria town, Nigeria.

\begin{tabular}{|c|c|c|c|c|}
\hline \multirow{2}{*}{ Preparation/processing step } & \multicolumn{3}{|l|}{ Hazard } & \multirow{2}{*}{ Control measure } \\
\hline & Biological & Chemical & Physical & \\
\hline $\begin{array}{l}\text { Suckling of lactating cow by } \\
\text { calves to initiate milk flow }\end{array}$ & $\begin{array}{l}\text { Enterics, spore forming } \\
\text { bacteria, yeasts and moulds }\end{array}$ & non & $\begin{array}{l}\text { Unclean/unsanitized udder, calve, } \\
\text { contaminated soil }\end{array}$ & $\begin{array}{l}\text { Standard cattle housing practices, good } \\
\text { hygiene practices, standard sanitation } \\
\text { practices for milking environment. }\end{array}$ \\
\hline $\begin{array}{l}\text { Manual milking into sun-dried } \\
\text { calabashes }\end{array}$ & $\begin{array}{l}\text { Enterics, spore forming } \\
\text { bacteria, yeasts and moulds }\end{array}$ & non & $\begin{array}{l}\text { Unsanitized udder, Milking } \\
\text { personnel, utensils (sundried } \\
\text { calabashes), milking environment }\end{array}$ & $\begin{array}{l}\text { Standard sanitary/hygiene practices in } \\
\text { disinfection of udder, hands of personnel, } \\
\text { utensils, milking environment. }\end{array}$ \\
\hline $\begin{array}{l}\text { Fermentation at ambient } \\
\text { temperature for } 24 \mathrm{~h}\end{array}$ & $\begin{array}{l}\text { Enterics, Spore forming } \\
\text { bacteria, yeasts and moulds }\end{array}$ & non & $\begin{array}{l}\text { Utensils (Sundried calabashes, } \\
\text { straw mats) }\end{array}$ & $\begin{array}{l}\text { Good manufacturing practices (heat treatment, } \\
\text { starter cultures, incubation temperature, final } \\
\mathrm{pH} \text { ), standard sanitary practices. }\end{array}$ \\
\hline $\begin{array}{l}\text { Fat removal/skimming of top fat } \\
\text { layer of fermented milk } \\
\text { (kindirmo) }\end{array}$ & $\begin{array}{l}\text { Enterics, spore forming bacteria } \\
\text { Yeasts and moulds, }\end{array}$ & non & $\begin{array}{l}\text { Utensils (spoons, straw mats, } \\
\text { calabashes) environment }\end{array}$ & Standard sanitary practices. \\
\hline $\begin{array}{l}\text { Addition of water to skimmed } \\
\text { fermented milk }\end{array}$ & $\begin{array}{l}\text { Enterics and other Pathogenic } \\
\text { bacteria, spore forming } \\
\text { bacteria, Yeasts and moulds, }\end{array}$ & water & $\begin{array}{l}\text { Utensils (calabashes, water } \\
\text { containers, wooden whisks) }\end{array}$ & $\begin{array}{l}\text { Good manufacturing practices, (water quality, } \\
\text { standard sanitary practices. }\end{array}$ \\
\hline $\begin{array}{l}\text { Nono held atambient } \\
\text { temperature before/during sale }\end{array}$ & $\begin{array}{l}\text { Enterics and other Pathogenic } \\
\text { bacteria, Yeasts and moulds, } \\
\text { sporeformers, }\end{array}$ & mycotoxins & $\begin{array}{l}\text { Utensils (calabashes, straw mats, } \\
\text { spoons, bowls) personnel, } \\
\text { environment }\end{array}$ & $\begin{array}{l}\text { Good manufacturing practices (holding time, } \\
\text { temperature), standard sanitary practices. }\end{array}$ \\
\hline
\end{tabular}


calabashes (IDF/FAO, 2004; Food Standards Agency, 2016).

Storage of unpasteurized raw milk samples had great potentials in promoting the growth and survival of the spoilage organisms in the milk samples. It was observed that pasteurization of milk was not employed by the producers, and it was gathered from one of the producers that they believed heat treatment would "destroy" the nutrients in the milk. Pasteurization is a critical step of milk processing which kills all pathogens and spoilage microorganisms and active acid forming bacteria that may have entered the milk (Sfakianakis and Tzia, 2014). Another critical step that was not employed before fermentation of milk is inoculation of the milk samples with starter cultures. Standard starter cultures used for milk fermentation into yoghurt contain two organisms, Streptococcus thermophilus and Lactobacillus bulgaricus which under optimum temperature rapidly reduces the $\mathrm{pH}$ of pasteurized milk to levels that are inhibitory for survival of most organisms (Mossel et al., 1995). Scientific evidence comparing spontaneous versus inoculated fermentation processes testify to the importance of the starter culture technology to assure safety of fermented food production. This safety is provided through biological activities such as faster acidification activity, domination of the indigenous microflora, reduction of fermentation time and reduction of undesired microbial strains/species and toxic compounds (De Angelis, 2015).

Temperature of the processing environments which ranged from 25 to $29^{\circ} \mathrm{C}$ during the study could also have contributed favourably to growth of the spoilage organisms as these temperatures are within the range of temperatures (below 10 to $45^{\circ} \mathrm{C}$ ) that favour the growth of coliforms, B. cereus, yeasts and moulds (Rivituso and Snyder, 1981; Barnett et al., 1983; Zwietering et al., 1991). Other factors that would have contributed to the multiplication of the spoilage organisms during storage are the $\mathrm{pH}(6.2$ to 6.7$)$ and inherent nutritional quality of the milk.

The resulting products obtained from storage of milk (nono) could therefore be said to be high-risk foods containing significantly high populations of possible pathogenic organisms. The products were further subjected to more contamination by the practice of scooping up the fat layer with contaminated utensils as was confirmed from microbial analysis of swabs of the utensils. The addition of water to the fat while shaking to separate the fat globules from the fermented milk could further have contaminated the products as the water samples were confirmed to contain some spoilage organisms. The conditions under which the products were held after production which involved collective packaging of different nono products into one big calabash and transporting them to the market by walking long distances under the hot sun, are such that would have contributed to high counts of the spoilage organisms in products. In this respect, it is of significance to note that counts of the spoilage organisms in products collected during traditional processing were lower than those of nono samples collected from the market. Similar observations have been reported by Davey, (1985) and Bryan, (1988). They observed that holding of food at ambient temperature for several hours resulted in increased counts of foodborne pathogens.

\section{Conclusion and recommendations}

Results of this study corroborates those of previous studies that have established the presence of spoilage and pathogenic microorganisms in nono, and for this study, at levels considered unsatisfactory. This study also established that hazards were associated with most steps of nono production and hence highlights the impact of substandard processing techniques and hygiene on the quality of nono. There is the need to educate and encourage the producers on the use of simple forms of standard hygiene and processing techniques as recommended by regulatory agencies, to improve the microbiological quality and safety of the product. Practices like washing of milk teats/udder before milking, washing of hands and utensils with soap, milk pasteurization and the use of standard starter cultures are simple tasks the producers can easily adopt, as it is also important to consider the general set up and cultural beliefs of a people when undertaking such

tasks.

\section{ACKNOWLEDGEMENT}

The researchers hereby acknowledge the support and contribution of Dr. E. Ella, Mr. Adamu Shittu, and Mr, A.G. Zubairu of the Department of Microbiology, Ahmadu Bello University, Zaria, kaduna state, Nigeria for their technical support. The tremendous support of Dr. S. Sarki of the Department of Applied Science, Kaduna Polytechnic in the course of the field trips undertaken during the study is also hereby acknowledged.

\section{CONFLICT OF INTEREST}

The authors declare that they have no conflict of interest.

\section{REFERENCES}

Abd El-Razik, M. M., Hassan, M. F., \& Gadallah, M. G. (2016). Implementation of HACCP plan for the production of Egyptian kishk (a traditional fermented cereal-milk mixture). Food and Nutrition Sciences, 7(13), 1262-1275.

Adams, M. R., \& Moss, M. O. (1999). Food Microbiology. Royal Society of Chemistry Cambridge, UK. P. 265.

Akabanda, F., Owusu-Kwarteng, J. R. L. K., Glover, R. L. K., \& 
Tano-Debrah, K. (2010). Microbiological characteristics of Ghanaian traditional fermented milk product, Nunu. Nature and Science, 8(9), 178-187.

Barnett, J. A., Payne, R. W., \& Yarrow, D. (1983). Yeasts: characteristics and identification. Cambridge university press. Pp. 19-28.

Bello, S., Whong, C. M. Z. \& Abdullahi, I. O. (2014). Prevalence of $B$. cereus in uncontrolled fermented cow milk and the influence of $\mathrm{pH}$ and temperature on its survival during storage. The International Journal of Engineering and Science, 3(12), 51-56.

Bryan, F. L. (1988). Risks of practices, procedures and processes that lead to outbreaks of foodborne diseases. Journal of Food Protection, 51(8), 663-673.

Bryan, F. L. (1992). Hazard analysis critical control point evaluations. A guide to identifying hazards and assessing risks associated with food preparation and storage. World Health Organization, Geneva. p. 3.

Capozzi, V., Fragasso, M., Romaniello, R., Berbegal, C., Russo, P., \& Spano, G. (2017). Spontaneous food fermentations and potential risks for human health. Fermentation, 3(4), 19p.

Centre for Food Safety (CFS) (2017). Seven principles of hazard analysis and critical control point (HACCP) system. Retrieved 14/07/2019 from http:// www.cfs.gov.hk.

Davey, G. P. (1985). Food poisoning in New south Wales: $1977-$ 1984. Food Technology, 37, 453-456

De Angelis, M., Campanella, D., Cosmai, L., Summo, C., Rizzello, C. G., \& Caponio, F. (2015). Microbiota and metabolome of un-started and started Greek-type fermentation of Bella di Cerignola table olives. Food Microbiology, 52, 1830.

Duguid, J. P., Marmion, B. P., \& Swain, R. H. A. (1984). Mackie and Mc Cartney Medical Microbiology. A guide to the Laboratory Diagnosis and Control of Infection. 13th edition, Volume 1: Microbial Infections. Churchill Livingstone Inc. New York. p. 641.

Egwim, E., Amanabo, M., Yahaya, A., \& Bello, M. (2013). Nigerian indigenous fermented foods: processes and prospects. Mycotoxin and food safety in developing countries. IntechOpen Science. Pp. 153-180.

Emmanuel, S. D., Adamu, I. K., Ejila, A., Yabaya A., Ja'afaru, M. I., Bobai, M., \& Blessing, Y. (2014). Quality assessment and occurrence of bacterial pathogens in locally available Fulani nono (milk), fermented yoghurt and their effect to humans. A case study of Samaru Zaria. International Journal of Current Research, 6(8), 8179-8185.

Food and Agricultural organization (FAO) (1979). Manuals of food quality control: A microbiological analysis. Food and Agricultural Organization of the United Nations, Italy. Pp. 1017.

Food Standards Agency (2016). Milk hygiene on the dairy farm. Retrieved 15th February, 2020 from http://food.gov.uk.

Holt, J. G. (1994). Bergey's manual of determinative bacteriology (9th edition). Williams and Wilkins, Baltimore, MA.

International Dairy Foundation/Food and Agricultural Organization (IDF/FAO) (2004). Guide to good dairy farming practice. Food and Agriculture Organization of the United Nations, Rome and International Dairy Federation, Brussels.

Ladan, M. S., \& Abiodun, A. A. (1990). Characteristics of strains of $E$. coli isolated from locally fermented milk (nono) in Zaria, Nigeria. Journal of Food Protection, 53(7), 574-576.

Lin, S., Schraft, H., Odumeru, J., \& Mansel, G. (1998). Identification of contamination sources of Bacillus cereus in pasteurized milk. International Journal of Food Microbiology,
43(3), 159-571.

Maikai, B. V., \& Madaki, P. D. (2018). Enumeration of coliforms in fermented milk product (nono) sold in Samaru, Kaduna State, Nigeria. Sokoto Journal of Veterinary Sciences, 16(4), 50-57.

Marco Maria, L., Heeney, D., Binda, S., Cifelli Christopher, J., D Paul, C., Foligne, B., Ganzle, M., Kort, R., Pasin, G., Pihlanto, A., \& Smid Eddy, J. (2017). Health benefits of fermented foods: microbiota and beyond. Current Opinion in Biotechnology, 44, 94-102.

Mats, P., Wiberg, C., \& Norberg, P. (1985). A research note; comparison of media for the isolation of Bacillus cereus from foods. Journal of Food Protection, 48,969-970.

Mohammed, A. S., \& Abdullahi, M. (2013). Comparative study of microbial quality of hawked nono and packaged yogurt sold in Bida metropolis. Specialty Journal of Psychology and Management, 1(0),1-4.

Mossel, D. A. A., Corry, J. E. L., Struijk, C. B., \& Baird, R. M. (1995). Essentials of the microbiology of foods: A textbook for advanced studies. John Wiley and Sons, England, Pp. 76-77.

Norrung, J., Anderson, K., and Buncic, S. (2009). Main concerns of pathogenic microorganisms in meat. In: Toldra, F. (ed.). Safety of meat and processed meat (pp. 3-29), Springer, New York, NY, USA.

NSW Food Authority (New South Wales) (2009). Microbiological quality guide for ready-to-eat food. A guide to interpreting microbiological result. Retrieved 16th August 2012 from. http://www.foodauthority.nsw.gov.au.

Okeke, O. F. I., \& Okwori, A. E. J. (2011). Occurrence of pathogenic yersinia species in locally fermented cow milk (nono) in Jos, nigeria. Nigerian Journal of Biotechnology, 23, 45-52.

Okonkwo, O. I. (2011). Microbiological analyses and safety evaluation of nono: A fermented milk product consumed in most parts of northern Nigeria. International Journal of Dairy Science, 6(3), 181-189.

Omotosho, A. O., Abdullahi, I. O., \& Damisa, D. (2013). Microbiological quality and HACCP concept in the production of nono in a farm settlement in Minna, Niger state, Nigeria. African Journal of Microbiology Research, 7(25), 3234-3239.

Préstamo, G., Pedrazuela, A., Guignon, B., \& Sanz, P. D. (2007). Synergy between high-pressure, temperature and ascorbic acid on the inactivation of Bacillus cereus. European Food Research and Technology, 225, Article number 693.

Rawat, S. (2015). food Spoilage: Microorganisms and their prevention. Asian Journal of Plant Science and Research, 5(4), 47-56.

Rivituso, C. P., \& Snyder, O. P. (1981). Bacterial growth at foodservice operating temperatures. Journal of Food Protection, 44(10), 770-775.

Sfakianakis, P., \& Tzia, C. (2014). Conventional and innovative Processing of milk for yoghurt manufacture: development of texture and flavor: A Review. Foods, 3(1), 176-193.

Shehu, L. M., \& Adesiyun, A. A. (1990). Characteristics of strains of Escherichia coli isolated from locally-fermented milk (nono) in Zaria, Nigeria. Journal of food protection, 53(7), 574-576.

Wogu, D., Omoruyi, M. I., Odeh, H. O., \& Guobadia, J. N. (2011). Microbial load in ready-to-eat rice sold in Benin City. Journal of Microbiology and Antimicrobials, 3(2), 29-33.

Zwietering, M. H., De Koos, J. T., Hasenack, B. E., De Witt, J. C., \& Van't Riet, K. (1991). Modeling of bacterial growth as a function of temperature. Applied and Environmental Microbiology, 57(4), 1094-110. 